\title{
REALIZATION OF TOTAL HARMONIC DISTORTION MEASUREMENT OF ACOUSTIC SOURCE SIGNAL SYSTEM FOR FREQUENCY OF 125 HZ AND 1000 $\mathrm{HZ}$
}

\author{
Realisasi Pengukuran Distorsi Harmonik Total Pada Sistem Sumber Sinyal Akustik \\ Untuk Frekuensi $125 \mathrm{~Hz}$ dan $1000 \mathrm{~Hz}$
}

\author{
Bondan Dwisetyo, Denny Hermawanto, Dodi Rusjadi, Chery Chaen Putri, \\ Maharani Ratna Palupi, and Fajar Budi Utomo
}

\author{
Center for Research and Human Resource Development - National Standardization Agency of Indonesia, \\ Kompleks Puspiptek Gedung 430, Setu, Tangerang Selatan, Banten, Indonesia 15314 \\ e-mail: bondan@bsn.go.id
}

Diterima: 2 Agustus 2019, Direvisi: 1 Oktober 2019, Disetujui: 14 November 2019

\begin{abstract}
The measurement of total harmonic distortion (THD) of an acoustic source signal system has carried out in Laboratory Acoustics and Vibration, Sub-directorate of National Measurement Standards for Acoustics and Vibration - BSN. The aim of this research is, therefore, to measure and analize the THD values that produced by the system that consists of a signal generator, a power amplifier, and a passive loudspeaker with fundamental frequencies of $125 \mathrm{~Hz}$ and $1000 \mathrm{~Hz}$. This measurement should be implemented because it has never been performed in this laboratory. Moreover, this system always be used for either calibration or measurement of acoustical instruments such as sound level meter and noise dosimeter. The method used to measure THD is a free field method using a full anechoic chamber with narrow band analysis. Measurand to determine THD is sound pressure level (SPL) with output of loudspeaker are $94 \mathrm{~dB}, 104 \mathrm{~dB}$, and $114 \mathrm{~dB}$. From result of measurement was found THD value of fundamental frequencies of $125 \mathrm{~Hz}$ and $1000 \mathrm{~Hz}$. For the former frequency, the maximum THD was found at SPL of $94 \mathrm{~dB}$ where its value was $1,86 \%$. Meanwhile the later, the maximum value of THD was 1,94 $\%$ also at SPL 94 of dB. The results of this measurement can be used into uncertainty budget for either calibration or testing of acoustical instruments, and also support for validation of calibration of noise dosimeter based on percentage of noise exposure dose using acoustic comparison coupler that still under research and development in this year.
\end{abstract}

Keywords: acoustic source signal system, sound pressure level, total harmonic distortion (THD)

\begin{abstract}
Abstrak
Telah dilakukan pengukuran distorsi harmonik total (THD) pada sistem sumber sinyal akustik di Laboratorium Akustik dan Vibrasi, Subdirektorat SNSU Akustik dan Vibrasi. Penelitian ini bertujuan untuk mengukur dan menganalisis nilai THD yang dihasilkan dari slstem sumber sinyal akustik yang terdiri dari pembangkit sinyal, penguat sinyal, dan loudspeaker pasif pada frekuensi fundamental $125 \mathrm{~Hz}$ dan $1000 \mathrm{~Hz}$. Pengukuran ini perlu diimplementasikan karena belum pernah dilakukan sebelumnya. Lebih jauh lagi, sistem tersebut selalu digunakan untuk kalibrasi dan pengukuran instrumen akustik seperti sound level meter dan noise dosimeter. Metode yang digunakan untuk mengukur THD adalah metode free field menggunakan ruang anti gema sempurna dengan narrow band analysis. Besaran ukur untuk menentukan THD adalah tingkat tekanan suara (SPL) dengan keluaran loudspeaker sebesar $94 \mathrm{~dB}, 104 \mathrm{~dB}$, dan $114 \mathrm{~dB}$. Dari hasil pengukuran, ditemukan nilai THD untuk frekuensi fundamental $125 \mathrm{~Hz}$ dan $1000 \mathrm{~Hz}$. Untuk frekeunsi $125 \mathrm{~Hz}$, Nilai THD maksimum yang diperoleh pada SPL $94 \mathrm{~dB}$ adalah sebesar 1,86 \%. Sedangkan pada frekeunsi fundamental $1000 \mathrm{~Hz}$, nilai THD maksimum sebesar 1,94\% juga pada SPL 94 dB. Hasil dari pengukuran ini dapat digunakan sebagai salah satu sumber ketidakpastian untuk kalibrasi dan pengukuran instrumen dan peralatan akustik di dalam ruang anti gema sempurna, dan mendukung kegiatan validasi untuk kalibrasi noise dosimeter berdasarkan dosis paparan kebisingan menggunakan acoustic comparison coupler yang masih dalam tahap penelitian dan pengembangan pada tahun ini.
\end{abstract}

Kata kunci: acoustic source signal system, tingkat tekanan suara, total harmonic distortion (THD)

\section{INTRODUCTION}

Deputy of National Measurement Standard BSN (Kedeputian SNSU-BSN), formerly was Research Center for Metrology LIPI (RCM-LIPI) has an acoustic source signal system that consists of a signal generator, a power amplifier, and a passive single directional loudspeaker. It is always used for calibrating and testing the acoustical instruments such as sound level meters, and noise dosimeters. The acoustic signal produced by this system will be distorted due to the harmonics, inhomogeneity of medium, self generated noise of the 
instrument, and others (Jaisiva, Neelan and llansezhian, 2016). This paper focuses only for the harmonics measurement because it has never been performed in the laboratory. Moreover, it probably can cause the error of reading in an unit under test (UUT) during calibration or testing (Corporation, 2015). Therefore, Research Group for Acoustics and Vibration, Center for Research and Human Resource Development BSN (Pusrisbang SDM - BSN), is necessary to measure and analyze its value. After that, it should be added as a correction of reading of UUT and also will be considered to be used to uncertainty budget for calibration result. However, if the value is smaller or still in limit of acceptance test (4\%) (IEC 60942 2017), it may be neglected.

The harmonic distortion is usually expressed as a total harmonic distortion (THD) (Kalibrasi et al., 2014). Measurement of THD can be conducted using a frequency analyzer. To reduce a background noise and sound reflection, it is necessary to use a full anechoic chamber as a measurement medium with narrow band analysis (Ginter and Margolis, 2013). According to IEC 61672-3, fundamental frequencies of $125 \mathrm{~Hz}$ and $1000 \mathrm{~Hz}$ and sound pressure levels of $94 \mathrm{~dB}, 104 \mathrm{~dB}$, and $114 \mathrm{~dB}$ are mandatory to be used for calibration of sound level meter and noise dosimeter (IEC 61672-3 2013).

The purpose of this work is, therefore, to measure and analize THD of the acoustic source signal system using a band pass filter and frequency analyzer at the aforementioned frequencies and sound pressure levels. In addition, the result of this measurement also support for validation process for calibration of noise dosimeter based on percentage of noise exposure dose using comparison coupler method that still under development in this laboratory

\section{BASIC THEORY}

In the principle, the sound wave that produced by a sound source is a pure sinusoidal wave ( Aswal, Singh, Agarwal, Sharma \& Sharma, 2016). However, on its propagation and transmission, it can be demodulated nonlinearly in the air, so it also contains the harmonic distortion (Masunaga, Ikefuji, Morise, Nakayama and Nishimura, 2012). It is a sinusoidal component of a periodic wave that its frequency is an integer which equals to multiple of a fundamental frequency. When the waves of a fundamental and harmonic frequency combine to form a superposition wave then the distorted wave is created (Corporation, 2015).
The forming of a non-sinusoidal wave due to the harmonic distortion is shown Figure 1.

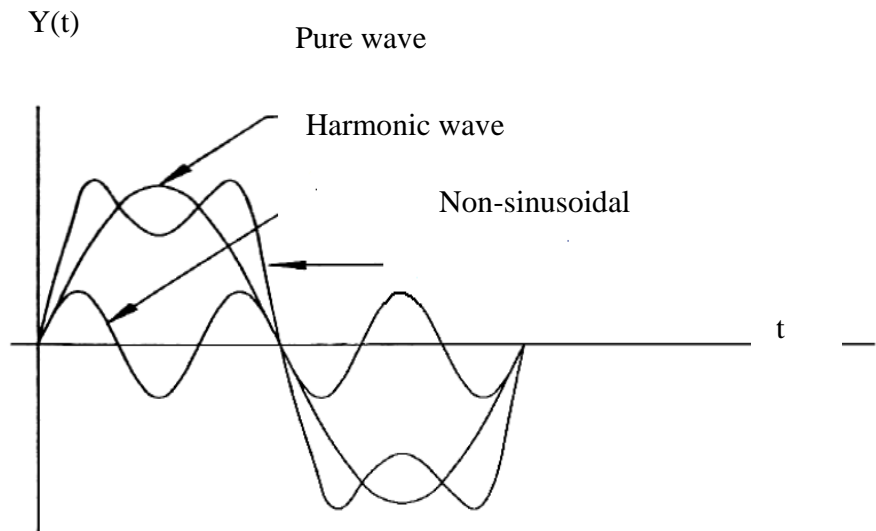

Figure 1 Superposition of the pure wave and the harmonic wave produces a non-sinusoidal wave.

In the acoustic source signal system, the pure wave of specified amplitude and frequency is generated by the signal generator. This wave is then amplified by the power amplifier with a specified gain, and hence its amplitude is bigger than before. Next, this electric signal is converted to the acoustic signal by the passive directional loudspeaker. This signal contains the harmonic component, and will combine with the original wave to form a non-sinusoidal signal. Further, this signal should be measured in a free field condition that basically, it can only be found in the particular area that has an infinite volume where the sound reflections is not detected. However, this conditions can be implemented in anechoic chambers that represent these conditions, where, it has a finite volume and some absorber to minimize the sound reflections (Pollard, Tran \& Letowski, 2013). Furthermore, the appropriate method that used to measure this signal is free field method, where, in this method, a sound source is placed inside the center of the chamber (Frederiksen 2013). Then, the receiver is installed at a distance of 1 meter of the source. With using analizer outside the chamber, sound pressure level can be measured.

After that, the signal can be calculated using fourier transform (Alegria, 2016) and the result is shown in equation 1 .

$Y(t)=Y_{0}+\sum_{n=1}^{n=\infty} Y_{n} \sqrt{2} \sin n 2 \pi f t-\varphi_{n}$ [1]

Where:

$Y_{(t)}=$ Output signal amplitude

$\mathrm{Y}_{0}=\mathrm{DC}$ amplitude

$Y_{n}=r m s$ value of harmonic component 


$$
\begin{aligned}
F & =\text { fundamental frequency } \\
\varphi_{n} & =\text { Phase of angle of harmonic } \\
& \text { component } \\
T & =\text { Time of propagation }
\end{aligned}
$$

The fourier analysis can be used to analyze sound pressure level (SPL) that represents as amplitude and frequency of the distorted signal (Meisami-asl, Sharifi, Mobli, Eyvani \& Alimardani, 2013). Representation of the fourier transform of the harmonic signals is shown in Figure 2.

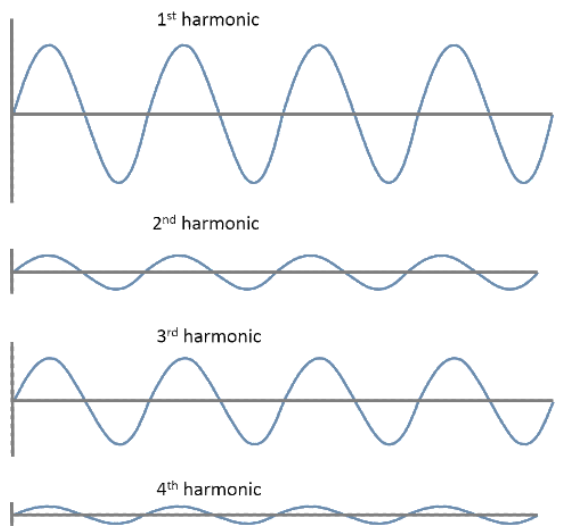

Figure 2 Representation of the fourier transform of the harmonic signals.

Figure 2 shows the result measured with a fundamental frequency of $1 \mathrm{kHz}$ at specified amplitude. The harmonic distortions occur at 2 $\mathrm{kHz}$ (1 ${ }^{\text {st }}$ harmonic), $3 \mathrm{kHz}$ (2 ${ }^{\text {nd }}$ harmonic), $4 \mathrm{kHz}$ ( $3^{\text {rd }}$ harmonic), and 5 ( $4^{\text {th }}$ harmonic) which are the integral multiplication frequency of an input sine wave (Huszty, Yokoyama and Sakamoto, 2010). In measurement, the harmonic distortion is usually expressed as THD that is defined as the ratio of the sum of the output signal of all harmonic components to the output signal of the fundamental frequency (Associated Power Technologies, 2011) and shown in equation 2.

$T H D=\sqrt{\frac{\sum_{n=2}^{n=\infty} M_{n}^{2}}{M_{1}}}$

Where:

$$
\begin{aligned}
\text { THD }= & \text { Total harmonic distortion (\%) } \\
M_{n}= & \text { The rms value of current or } \\
& \text { voltage on harmonic } \\
M_{1}= & \begin{array}{l}
\text { The rms value of current or } \\
\text { voltage on fundamental frequency }
\end{array}
\end{aligned}
$$

\section{METHODS}

There are some methods to measure THD of an acoustic source signal system, such as electrical test and free field methods (Ginter and Margolis, 2013). The former can be applied using time selective response technique without a loudspeaker, while the later can be performed with it. In this work, the second method was chosen to measure THD with narrow band analysis, because the loudspeaker as a part of acoustic source signal systems always be used for calibration and testing of acoustical instruments such as sound level meters and noise dosimeters in BSN. In this method, the loudspeaker and the microphoneis installed in the center of the full anechoic chamber. To determine the THD value, it is necessary to use a band pass filter and a frequency analyzer.

The equipment used in measurement of THD are as follow:

1. The signal generator

Fluke 282 Arbitrary Waveform Generator:

Double channel, frequency range $0,1 \mathrm{mHz}-16$ $\mathrm{MHz}$, resolution 7 digits, frequency accuracy 10 ppm/year, output level $25 \mathrm{mV}$ to $10 \mathrm{~V} \mathrm{p}$-p into $50 \Omega$

\section{Decade selector/attenuator}

GDS EL 100:

Resolution 4 digits, input impedance $600 \Omega$

\section{Power amplifier}

Brüel \& Kjær type 2716:

Maximum voltage gain $30 \mathrm{~dB}$, frequency response $20 \mathrm{~Hz}$ - $20 \mathrm{kHz}$, output impedance $0,03 \Omega$

\section{Passive directional loudspeaker}

Frequency range $31.5 \mathrm{~Hz}-10 \mathrm{kHz}$

\section{Digital voltmeter}

Fluke 2147 1/2 Digits

6. Multi-frequency sound calibrator

Brüel \& Kjær type 4231:

Class LS sound calibrator conform to IEC 60694, SPL 94, 104 and 114 dB, Multi Frequency

7. Standard microphone LS2

Brüel \& Kjær type 4180

Primary standard of acoustic measurement

8. Measuring amplifier

Brüel \& Kjær type 4231

9. Band pass filter

Brüel \& Kjær type 1621

10.Pulse analyzer

Brüel \& Kjær type 3650-C

PC with LAN interface, PULSE software, and IDAe-based data acquisition front-end hardware

11.Full anechoic chamber 
Dimension $10 \mathrm{~m} \times 10 \mathrm{~m} \times 10 \mathrm{~m}$, rock wool absorber, $0,1 \mathrm{~dB}$ deviation due to characterization and positioning of unit under test at 1 meter in front of a sound source.

In this work, an experiment was set up using the aforementioned equipment and the first step is shown in Figure 3. A standard microphone LS2 was placed inside the full anechoic chamber and was connected to a measuring amplifier and a digital voltmeter inside a control room. Next, this microphone was putted off to a coupler of the multi frequency sound calibrator. By selecting frequency of $125 \mathrm{~Hz}$ and sound pressure levels at $94 \mathrm{~dB}, 104 \mathrm{~dB}$, and $114 \mathrm{~dB}$ of this sound calibrator, the signal is generated, and thereafter is detected by the microphone. The value of signal is indicated by the digital voltmeter in volt. Further, it is taken as a reference voltage to measure the THD for fundamental frequency of $125 \mathrm{~Hz}$.

\section{FULL ANECHOIC ROOM}

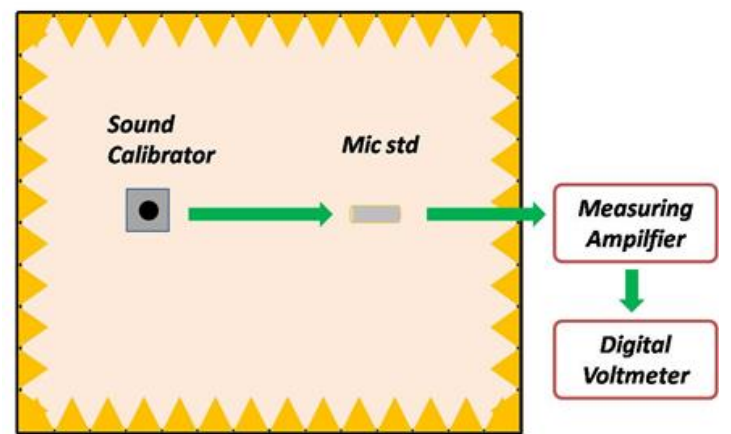

Figure 3 System of equipment to determine a reference voltage.

The second step in the experiment is shown in Figure 4. The standard microphone was installed at the distance of 1 meter from the loudspeaker. Then by configuring the attenuator at normal condition and the power amplifier gain at $5 \mathrm{~dB}$, they are arranged as that shown in Figure 4.

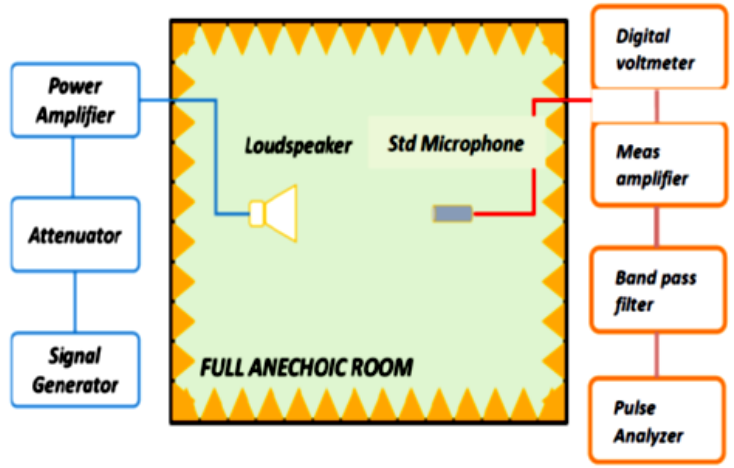

Figure 4 System of equipment of THD measurement.
Thirdly, frequency of $125 \mathrm{~Hz}$ was selected by configuring the signal generator menu. After that, by adjusting digits of the attenuator, the digital voltmeter was arranged so to make the display indicated the same value as the reference voltage for sound pressure level of $94 \mathrm{~dB}, 104 \mathrm{~dB}$, and $114 \mathrm{~dB}$.

Subsequently, the measuring amplifier is connected to the bandpass filter. In order to avoid bypass signal, it is necessary to be configured this filter device by selecting filter bandwidth is $3 \%$ and specified frequency range is $200 \mathrm{~Hz}-20 \mathrm{kHz}$.

Finally, by controlling frequency tunning of the filter, and then selecting window (flat-top) of the pulse analyzer, the harmonic distortion can be monitored and analyzed directly through this analyzer and displayed in the personal computer. For fundamental frequency of 1000 $\mathrm{Hz}$, all the above same steps also applied.

\section{RESULT AND DISCUSSION}

The result of THD measurement for fundamental frequency of $125 \mathrm{~Hz}$ and $1000 \mathrm{~Hz}$ at SPL $94 \mathrm{~dB}$ are shown in Figure 5 and Figure 6.

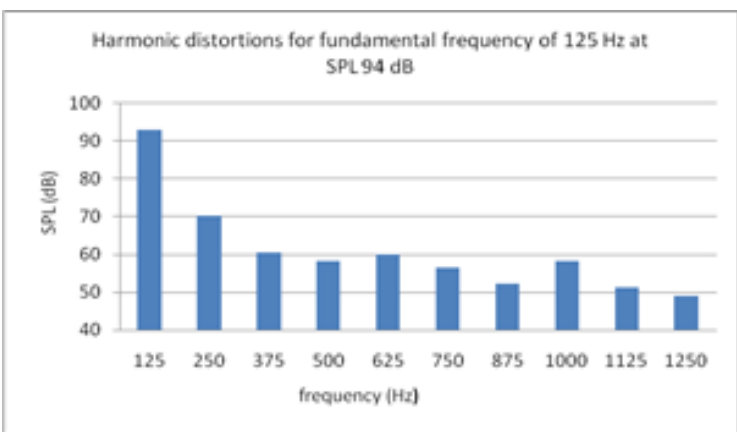

Figure 5 Harmonic distortions of fundamental frequency of $125 \mathrm{~Hz}$ at SPL of $94 \mathrm{~dB}$.

From figure 5, at fundamental frequency of $125 \mathrm{~Hz}$ it is shown that at the $1^{\text {st }}$ harmonic the SPL is $70,3 \mathrm{~dB}$ and tends to decrease until about 58,2 dB at the $3^{\text {rd }}$ harmonic. The SPL values then go up at $625 \mathrm{~Hz}$ that represents the $4^{\text {th }}$ harmonic about $60,1 \mathrm{~dB}$ and go down about $52,3 \mathrm{~dB}$ to the $6^{\text {th }}$ harmonic. Then, the SPL values increase about $58,2 \mathrm{~dB}$ at the $7^{\text {th }}$ harmonic and tends to decrease to a minimum value of about $49,1 \mathrm{~dB}$ at the last harmonic (1250 Hz). 


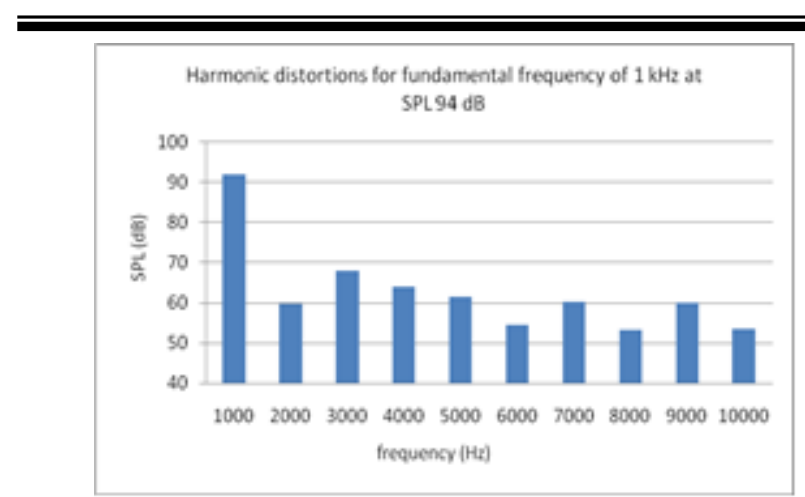

Figure 6 Harmonic distortions of fundamental frequency of $1000 \mathrm{~Hz}$ at SPL of $94 \mathrm{~dB}$.

Meanwhile, for fundamental frequency of $1000 \mathrm{~Hz}$ is shown in figure 6. It has slightly different of the curve trend with frequency of $125 \mathrm{~Hz}$. At this frequency, it is shown that the SPL values increase from the $1^{\text {st }}$ harmonic that the corresponding SPL is $59,2 \mathrm{~dB}$ to the maximum value at the $2^{\text {nd }}$ harmonic that its SPL is $70,3 \mathrm{~dB}$. From this frequency, the SPL values has a tendency to decrease until the $5^{\text {th }}$ harmonic that has SPL value is $56,2 \mathrm{~dB}$. After that, the SPL values go up and go down beyond this frequency where it has a minimum value is $49,1 \mathrm{~dB}$ at the last harmonic.

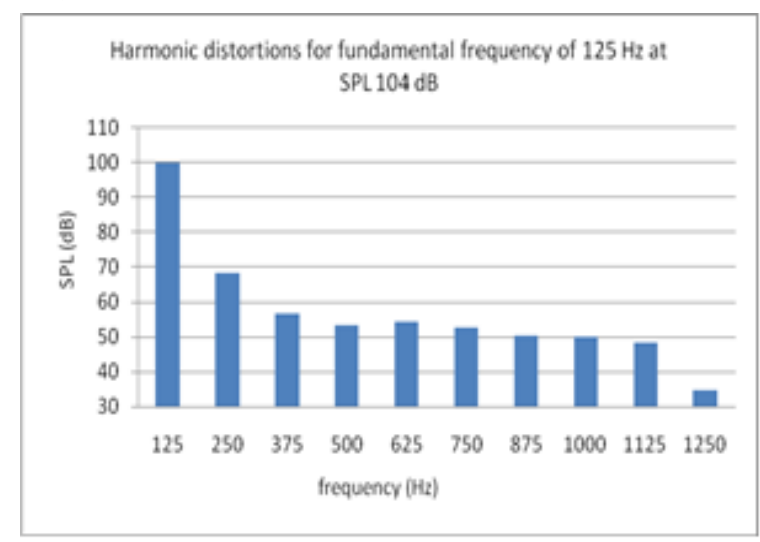

Figure 7 Harmonic distortions of fundamental frequency of $125 \mathrm{~Hz}$ at SPL of $104 \mathrm{~dB}$.

In Figure 5 and Figure 6, it is found that at fundamental frequency of $125 \mathrm{~Hz}$, it has a bigger of the SPL values than fundamental frequency of $1000 \mathrm{~Hz}$ at the $1^{\text {st }}$ harmonic, the $5^{\text {th }}$ harmonic, and the $7^{\text {th }}$ harmonic. Meanwhile, the other harmonics at fundamental frequency of $1000 \mathrm{~Hz}$ has a bigger SPL values. From these SPL values, the THD can later be calculated using the equation (2), where it is obtained that the acoustic source of $125 \mathrm{~Hz}$ has the THD is about $1,86 \%$, whilst for frequency of $1000 \mathrm{~Hz}$ is $1,94 \%$.

The result of THD measurement for SPL $104 \mathrm{~dB}$ at fundamental frequency of $125 \mathrm{~Hz}$ and $1000 \mathrm{~Hz}$ are shown in Figure 7 and Figure 8.
Harmonic distortions for fundamental frequency of $1 \mathrm{kHz}$ at SPL $104 \mathrm{~d} B$

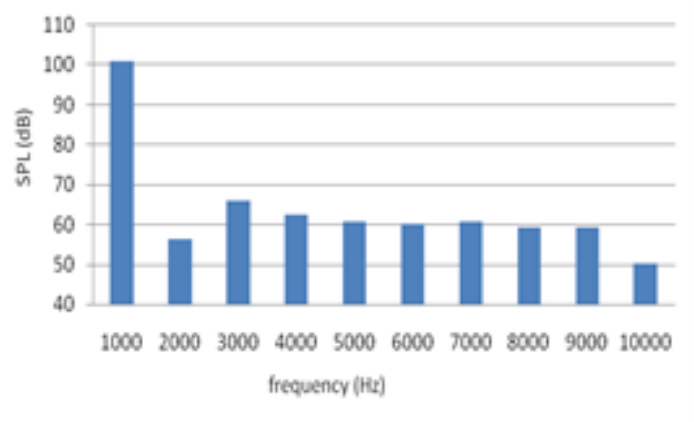

Figure 8 Harmonic distortions of fundamental frequency of $1000 \mathrm{~Hz}$ at SPL of $104 \mathrm{~dB}$.

From figure 7 , it shown that for fundamental frequency of $125 \mathrm{~Hz}$, the SPL values decrease from the $1^{\text {st }}$ harmonic that the SPL is $68,3 \mathrm{~dB}$ until $53,4 \mathrm{~dB}$ at the $3^{\text {rd }}$ harmonic. Hereafter, the SPL values go up at the $4^{\text {th }}$ harmonic about $60,1 \mathrm{~dB}$ and it has tendency to decrease until the minimum value at the last harmonic that its SPL about 34,7 dB.

Whilst, the different of curve trend is found at fundamental frequency of $1000 \mathrm{~Hz}$ that is shown in figure 8. At this frequency, it is shown that the SPL values increase from the $1^{\text {st }}$ harmonic that the corresponding SPL is $56,3 \mathrm{~dB}$ to the maximum value is about $70,3 \mathrm{~dB}$ at the $2^{\text {nd }}$ harmonic. After that, the SPL values tends to decrease until the minimum value at the last harmonic that its SPL is $50,2 \mathrm{~dB}$.

From both of these frequencies, it is found that at frequency of $125 \mathrm{~Hz}$, it has a bigger of the SPL value only at the $1^{\text {st }}$ harmonic. Furthermore, the SPL of next harmonics has the bigger value at frequency of $1000 \mathrm{~Hz}$. Subsequently, the THD can be calculated using the equation (2), where it is obtained that the acoustic sound of $125 \mathrm{~Hz}$ has the THD is about $1,58 \%$, whilst the THD of sound source of 1000 $\mathrm{Hz}$ is about $1,77 \%$.

The result of THD measurement for fundamental frequency of $125 \mathrm{~Hz}$ and $1000 \mathrm{~Hz}$ at SPL $114 \mathrm{~dB}$ can bee seen in Figure 9 and Figure 10. 
Harmonic distortions for fundamental frequency of $125 \mathrm{~Hz}$ at SPL $114 \mathrm{~dB}$

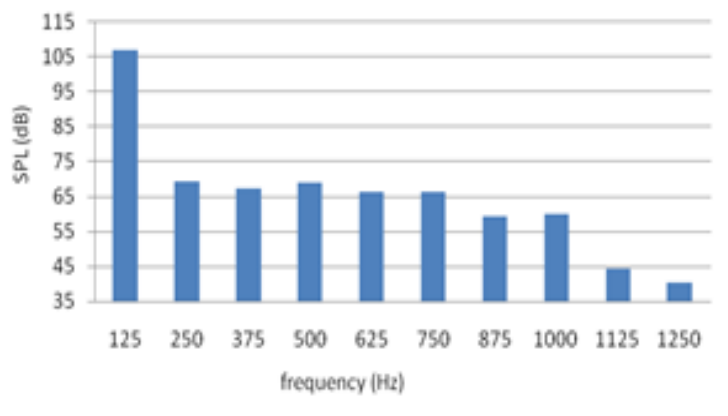

Figure 9 Harmonic distortions of fundamental frequency of $125 \mathrm{~Hz}$ at SPL of $114 \mathrm{~dB}$.

From figure 9 , it is shown that the $1^{\text {st }}$ harmonic the corresponding SPL is $69,3 \mathrm{~dB}$. After that, the SPL values decrease about 67,5 $\mathrm{dB}$ at the $2^{\text {nd }}$ harmonic. After that, The SPL go up and go down until the minimum value at the last harmonic that its SPL is about $40,3 \mathrm{~dB}$.

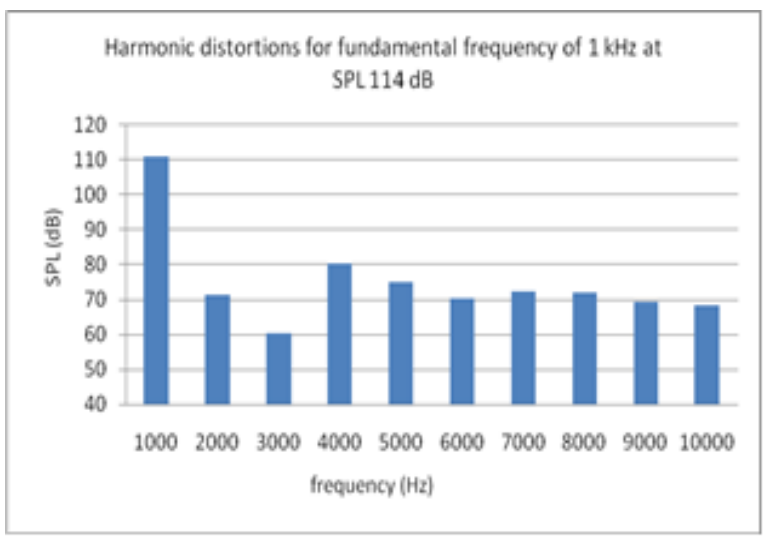

Figure 10 Harmonic distortions of fundamental frequency of $125 \mathrm{~Hz}$ at SPL of $114 \mathrm{~dB}$.

Meanwhile, In figure 10 can be seen that at the $1^{\text {st }}$ harmonic, the corresponding SPL is $70,3 \mathrm{~dB}$ and tends to decrease to the minimum value about $60,2 \mathrm{~dB}$ at the $2^{\text {nd }}$ harmonic. Then the SPL go up at $3^{\text {rd }}$ harmonic with the maximum value about $80,3 \mathrm{~dB}$ and go down about $52,3 \mathrm{~dB}$ until the $5^{\text {th }}$ harmonic. After that, the SPL values increase about $70,5 \mathrm{~dB}$ at the $7^{\text {th }}$ harmonic. Hereafter, the SPL values lean to decrease to about $68,4 \mathrm{~dB}$ at the last harmonic.

From these frequencies, it is found that at frequency of $125 \mathrm{~Hz}$, it has a bigger of the SPL value only at the $2^{\text {nd }}$ harmonic. Otherwise, this harmonic order has the minimum value for frequency of $1000 \mathrm{~Hz}$. Furthermore, the SPL of the next harmonics has the bigger value at frequency fundamental of $1000 \mathrm{~Hz}$. Subsequently, the THD can be calculated using the equation (2), where it is obtained that for frequency of $125 \mathrm{~Hz}$ has the THD is $1,71 \%$, whilst for frequency of $1000 \mathrm{~Hz}$ is $1,92 \%$.

The THD values that are determined from this experiment are in tolerance limit, where its magnitudes are not more than limit of acceptance test that its maximum permissible value is $4 \%$. In order to get a comparation result, in addition, it is recommended to be compared and validated using the calibrated THD meter where the values can be measured through this instrument directly. However, due to the calibration system of THD meter is still under research in BSN, the validation is not performed yet.

\section{CONCLUSION}

In this work, the measurement of the total harmonic distortion of the acoustic sources signal system at frequency fundamental $125 \mathrm{~Hz}$ and $1000 \mathrm{~Hz}$ was applied at Deputy of National Measurement Standard BSN (Kedeputian SNSU-BSN) by Research Group for Acoustics and Vibration, Center for Research and Human Resource Development BSN (Pusrisbang SDM - BSN). In fundamental frequency of $125 \mathrm{~Hz}$, the maximum THD was found at SPL of $94 \mathrm{~dB}$ where its value is $1,86 \%$. Meanwhile the later, the maximum value of THD was obtained is $1,94 \%$ also at SPL of $94 \mathrm{~dB}$. In conclusion, eventhough the THD values of the aforementioned frequencies can be added into uncertainty budget on calibration or testing of acoustical instruments, however, it can be neglected because these values are less than the maximum acceptance limit that its value is $4 \%$.

\section{ACKNOWLEDGEMENT}

The authors acknowledge the financial support from Ministry of Research, Technology, and Higher Education the Republic of Indonesia through the scheme of Incentive Research Program for the National Innovation System (05/INS-1/PPK/E4/2019).

In addition, we are also immensely grateful to Prof. Jimmy Pusaka and Mr. Santosa Prajitna Sugondo for the guidance and comments that greatly improved this paper.

\section{REFERENCES}

Alegria, F. C. (2016). Precision of the sinefittingbased total harmonic distortion estimator. Metrology and Measurement Systems, 23(1), 37-46. 
Associated Power Technologies. (2011). Total harmonic distortion and effects in electrical power systems. Apt (Figure 1), $1-4$.

http://www.aspowertechnologies.com/re sources/pdf/Total Harmonic Distortion. pdf.

Aswal, P., Singh, S. K., Agarwal, N., Sharma, V., \& Sharma, G. (2016). Total harmonic distortion at fault in RLC load. Indonesian Journal of Electrical Engineering and Computer Science, 4(2), 325-332.

Corporation, Microsemi. (2015). Basic total harmonic Measurement,30, 1-7.

Ginter, S. M., \& Margolis, R. H. (2013). Acoustic method for calibration of audiometric bone vibrators. II. Harmonic distortion. The Journal of the Acoustical Society of America, 134(1), EL33-EL37.

Huszty, C., Yokoyama, S., \& Sakamoto, S. (2010). Application of analytic sweep segments in room acoustic measurements. Red (Brownian), 6, 2.

IEC 60942. (2017). Sound calibrator. International Electroacoustics Commision.
IEC 61672-3. (2013). Electroacoustics-sound level meters-part 3: Periodic test. International Electroacoustics Commision.

Jaisiva, $\mathrm{S}$, Neelan, $\mathrm{S}$ and llansezhian, $\mathrm{T}$. (2016). Harmonic analysis in non - linear loads of power system.IRJET,3, 147478.

Kalibrasi, Sistem et al. (2014).Harmonisasi calibration system for evaluating a harmonic analyzer performance. 18798.

Masunaga, S., Ikefuji, D., Morise, M., Nakayama, M., \& Nishimura, T. (2012). Harmonic distortion measurement for a parametric loudspeaker with logarithmic time stretched pulse. Proc. Acoust, 12.

Meisami-asl, E., Sharifi, A., Mobli, H., Eyvani, A., \& Alimardani, R. (2013). On-site measurement of soil moisture content using an acoustic system. Agricultural Engineering International: CIGR Journal, 15(4), 1-8.

Pollard, K. A., Tran, P. K., \& Letowski, T. R. (2013). A free-field method to calibrate bone conduction transducers. The Journal of the Acoustical Society of America, 133(2), 858-865. 
